\title{
Studies on the mycoflora associated with sewage water in Bagru and Jharna area (Rajasthan)
}

\author{
Richa Sharma ${ }^{1 \star}$, Swati ${ }^{1}$, Gajanand Sharma ${ }^{2}$ and Meenakshi Sharma ${ }^{3}$ \\ ${ }^{1}$ Department of Biotechnology and Allied Sciences, Jayoti Vidyapeeth Women's University, Jaipur, India. \\ ${ }^{2}$ Department of Chemical Science, Suresh Gyan Vihar University, Jaipur, India. \\ ${ }^{3}$ Department of Botany, University of Rajasthan, Jaipur, India.
}

\begin{abstract}
Accepted 8 August, 2012
The wastewater in Bagru and Jharna area (Rajasthan) is rich in pathogenic and non-pathogenic keratinophilic fungi including dermatophytes. Most of the fungal isolates from the waste water have already been reported as dermatophytes causing infections of skin, scalps or hair. This study deals with the isolation and characterization of keratinophilic fungi from different water samples of Bagru and Jharna area (Rajasthan). Eighteen different fungi were isolated out of twenty water samples using a spread plate method. These fungal isolates were Epidermatophyton floccosum, Microsporum ferrugineum, Microsporum gypseum, Microsporum cookei, Microsporum canis, Trichophyton rubrum, Trichophyton mentagrophytes, Trichophyton concentricum, Trichophyton verrucosum, Trichophyton violaceum, other fungi were Aspergillus niger, Aspergillus fumigatus, Aspergillus flavus, Aspergillus terreus, Rhizopus oryzae, Penicillium sp., Fusarium oxysporum and Chrysosporium tropicum. Our result concluded that these isolated fungi are pathogenic for animals and human beings. Keratinophilic fungi play an important role in degradation of keratin and they are known to cause superficial cutaneous infections.
\end{abstract}

Key words: Keratinophilic fungi, pathogenic, non-pathogenic, spread plate method, superficial cutaneous infections, dermatophytes.

\section{INTRODUCTION}

Polluted water is a dynamic medium in which a large number of keratinophilic and non-keratinophilic fungus live in close association. Some keratinophilic fungi are pathogenic to animals including human beings. The biodiversity of keratinophilic fungal communities occurs both in soils and wastewater habitat (Hoog, 1996). The first discovery of keratinophilic fungi from soil was hair baiting technique, the most common method used for a qualitative and quantitative isolation of these fungi from soil (Kunert et al., 2000). Then the first discovery of keratinophilic fungi from waste water was conducted using membrane bioreactors (MBR) (Awad and Kraume, 2011). These fungi are natural colonizers on keratinic substances. Some are keratinolytic and play an important

${ }^{*}$ Corresponding author. E-mail: richa.phd.15@gmail.com. Tel: 09309045804. ecological role in decomposing $\alpha$ - keratin, the insoluble fibrous protein. Because of tight packing of hair polypeptide chain in $\alpha$ - helix structures and their linkage by disulphide bonds, they are poorly biodegradable (Kunert et al., 2000). This tough, fibrous and insoluble material provided an outer coat that served to prevent the loss of body fluids. Keratins have since proliferated into a wide variety of substances performing many different functions: the claws and armour of reptiles, the feather and beaks of birds, and the hooves, horns, skin, hair and nails of mammals. Thus keratin is an extremely strong protein which is a major component in skin, hair, nails, hooves, horns, and teeth. The amino acids which combine to form keratin have several unique properties, and depending on the levels of the various amino acids, keratin can be inflexible and hard like hooves, or soft, as is the case with skin. So according to sulphur contents keratins are grouped into hard keratin that is, feather, hair, hoof and nails or soft keratins that is, skin and 

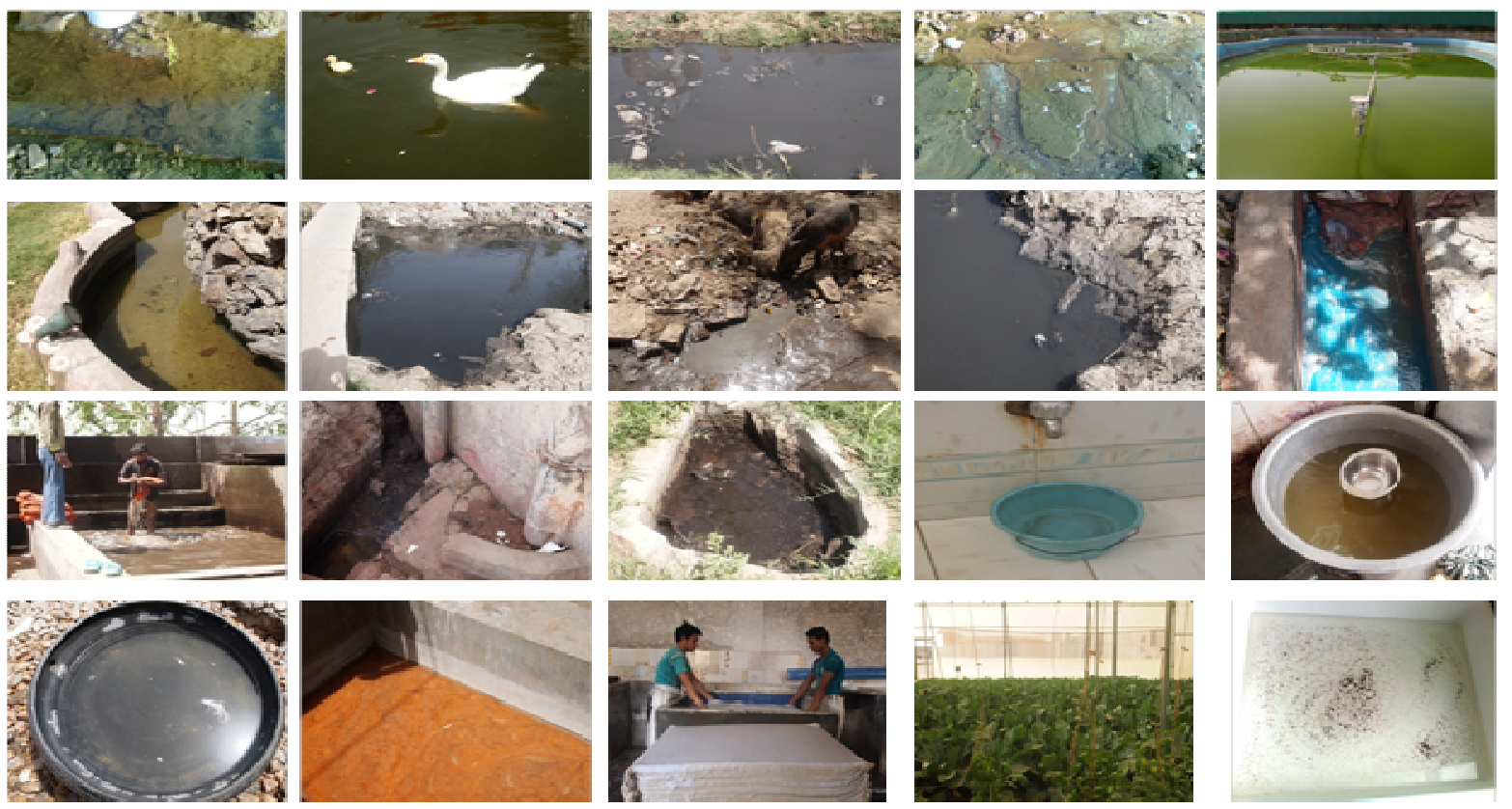

Figure 1. Collection of water samples from various habitats of Jharna and Bagru area (Rajasthan).

callus. Some of these as dermatophytes and they are known to cause superficial cutaneous infections (Dermatophytosis) of keratinized tissues (skin, hair, and nails) of humans and animals. Mycotic infection is reported throughout the world and is extremely contagious (Mandeel et al., 2009). Both dermatophytes and non-dermatophytes can colonize and invade skin, nails and hair (Deshmukh et al., 2008). The occurrence of dermatophytes and other keratinophilic fungi enhances the risk of human dermatophytes. In the recent years, many residents have reported the distribution of keratinophilic fungi and related dermatophytes in soils. (Hedayati et al., 2004). So far not many works have been carried out from water samples. Our present study reports the occurrence of keratinophilic fungi in the water samples of Bagru and Jharna area (Rajasthan) which causes superficial mycosis of human beings and animals.

\section{MATERIALS AND METHODS}

\section{Collection of sample}

Twenty different polluted water samples were collected in sterile screw vial tubes from various habitats viz. farm houses, ponds and textile industry of Jharna and Bagru region (Rajasthan) shown in (Figure 1) and brought to laboratories for further microbiological analysis.

\section{Physical properties}

The collected water samples were analyzed for the following physico- chemical parameters like $\mathrm{pH}$, temperature, electronic conductivity, total dissolve solid, salinity, dissolve oxygen, chemical oxygen demand and chloride content. The $\mathrm{pH}$, electrical conductivity, total dissolved solids, salinity parameters were analyzed by using up based water analysis kit and the other parameters viz. dissolved oxygen, chemical oxygen demand and chloride content were analyzed by adopting standard procedures.

\section{Isolation of fungi}

The fungi were isolated by spread plate method on Sabouraud's Dextrose Agar (SDA) media. For the isolation of keratinophilic fungi four different keratin substrate that is, human hair, nails, duck feather and pigeon feather were used. The substrate and the water samples were spread on the SDA plate and incubated at $28^{\circ} \mathrm{C}$ for 8 to 20 days.

\section{Identification of isolated fungi}

\section{Macroscopic identification}

For the macroscopic identification different selective media were used. Sabouraud's Dextrose Agar (SDA), Trichophyton Agar, Lactritmel Agar, Sabouraud's Chloramphenicol Dextrose Agar and Rice media were used for the growth and sporulation of different fungi.

\section{Microscopic identification}

Morphological characteristics were examined under microscope. Slide culture technique was adopted for the identification of fungi with lacto phenol cotton blue.

\section{Biochemical identification}

\section{Urease test}

Urea Agar media slants were prepared. Slants were inoculated from 
Table 1. Physico- chemical parameters of collected water samples from various habitats.

\begin{tabular}{|c|c|c|c|c|c|c|c|c|c|}
\hline S/no & Water samples & pH & $\begin{array}{l}\text { Temp. } \\
\left({ }^{\circ} \mathrm{C}\right)\end{array}$ & $\begin{array}{l}\mathrm{EC} \\
(\mathrm{ms})\end{array}$ & $\begin{array}{l}\text { TDS } \\
(\mathrm{mg} / \mathrm{l})\end{array}$ & $\begin{array}{l}\text { Salinity } \\
(\mathrm{mg} / \mathrm{l})\end{array}$ & $\begin{array}{c}\mathrm{DO} \\
(\mathrm{mg} / \mathrm{l})\end{array}$ & $\begin{array}{l}\text { COD } \\
(\mathrm{mg} / \mathrm{l})\end{array}$ & $\begin{array}{c}\text { Cl content } \\
(\mathrm{mg} / \mathrm{l})\end{array}$ \\
\hline 1. & Sewage water (Jharna) & 8.21 & 28.9 & 2.67 & 844 & 201 & 21.6 & 224 & 369 \\
\hline 2. & Pond water 1 (Jharna) & 6.69 & 26.8 & 3.16 & 262 & 158 & 21.2 & 48 & 142 \\
\hline 3. & Pond water 2 (Jharna) & 6.92 & 26.6 & 2.48 & 121 & 140 & 25.2 & 104 & 124 \\
\hline 4. & Duck Pond water (Jharna) & 6.25 & 27.0 & 5.34 & 347 & 379 & 14.4 & 64 & 94 \\
\hline 5. & Wash room water 1 (Jharna) & 7.12 & 28.6 & 1.57 & 101 & 123 & 14 & 40 & 69 \\
\hline 6. & Wash room water 2 (Jharna) & 6.94 & 28.9 & 2.40 & 119 & 138 & 15.2 & 144 & 35 \\
\hline 7. & Wash room water 3 (Jharna) & 6.58 & 27.8 & 1.45 & 695 & 188 & 19.6 & 32 & 105 \\
\hline 8. & Pig polluted water (Bagru) & 8.58 & 28.2 & 5.74 & 374 & 431 & 14 & 144 & 71 \\
\hline 9. & Tube's stagnant water (Bagru) & 8.67 & 27.9 & 5.89 & 378 & 435 & 12.4 & 224 & 126 \\
\hline 10 & Dye hand wash water (Bagru) & 8.14 & 27.6 & 1.37 & 73 & 85 & 16.4 & 32 & 75 \\
\hline 11 & Sink water (Jharna) & 7.34 & 26.9 & 2.36 & 112 & 176 & 106.0 & 16 & 823 \\
\hline 12 & Washing water of Dye cloths (Bagru) & 6.96 & 26.6 & 4.11 & 265 & 321 & 60.0 & 456 & 756 \\
\hline 13 & $\begin{array}{l}\text { Gut's stagnant water near dye textile } \\
\text { industry (Bagru) }\end{array}$ & 7.5 & 26.9 & 4.27 & 290 & 310 & 44.0 & 16 & 621 \\
\hline 14 & Farmer's field water (Jharna) & 6.9 & 27.0 & 4.14 & 276 & 318 & 70.0 & 48 & 876 \\
\hline 15 & $\begin{array}{l}\text { Tube's stagnant water near paper pulp } \\
\text { industry }\end{array}$ & 7.8 & 27.2 & 2.59 & 102 & 110 & 65.0 & 40 & - \\
\hline 16 & Gut's water near paper and pulp industry & 8.7 & 26.6 & 1.66 & 107 & 124 & 20.0 & 40 & 426 \\
\hline 17 & Stagnant water near $200 \mathrm{ft}$. & 7.7 & 27.2 & 0.76 & 50 & 156 & 42.0 & 80 & 852 \\
\hline 18 & Canteen sink water & 6.08 & 27.0 & 2.49 & 167 & 191 & 17.6 & 96 & 788 \\
\hline 19 & Duck drinking pond's water (Jharna) & 6.77 & 27.3 & 2.99 & 156 & 224 & 70.0 & 136 & 111 \\
\hline 20 & Ditches water near farm house (Bagru) & 7.7 & 28.6 & 4.18 & 281 & 322 & 40.0 & 176 & 639 \\
\hline
\end{tabular}

the isolated fungi then incubated at $28^{\circ} \mathrm{C}$ for 4 to 6 days. Colour change from yellow to pink indicates positive urease activity.

\section{Keratinase test}

The keratinolytic properties of the fungi were examined on a solid mineral medium according to Wawrzkiewicz et al. (1991). The media was supplemented with the keratin substrate as the sole sources of carbon and nitrogen. Preparation of soluble keratin protein was constituted from feathers where $10 \mathrm{~g}$ of native feathers where $10 \mathrm{~g}$ native feathers is dissolved with $500 \mathrm{ml}$ of DMSO (Dimethylsulfoxide) by heating at $100^{\circ} \mathrm{C}$ temperature for $2 \mathrm{~h}$. Solution was precipitated for soluble protein (keratin) by using 2 volume of cold acetone for 1 volume of protein and then caseous precipitate of keratin protein was suspended in $0.1 \mathrm{M}$ of phosphate buffer. Afterwards, soluble keratin protein was added in the solid media at a concentration of $0.06 \%$. Solid media were inoculated with micropipette, injecting $1 \mathrm{ml}$ of standard suspension into center of the petriplates and petriplates were incubated at $37^{\circ} \mathrm{C}$ at an optimum $\mathrm{pH} 7.4$ for keratinase activity. Control plates were prepared containing above medium without keratin substrate. Formations of precipitate zones around the colonies indicate keratinase enzyme production and zone was examined and measured.

\section{Extracellular enzyme detection}

The enzymes assayed for isolated fungi were amylase and protease. The solid media technique was employed for the extra- cellular enzyme detection (Berkenkamo, 1973).

\section{RESULTS AND DISCUSSION}

The results of isolation of keratinophilic fungi are presented in Tables 2, 3, 4 and 5. The data reveals that out of twenty water samples collected, eighteen species of keratinophilic and non- keratinophilic fungi were isolated from different water samples with different keratin substrates such as hair (human and animals) nails and feathers (duck and pigeon). In our present study, the maximum numbers of keratinophilic fungi were isolated from habitats of duck pond water, textile industry water, farmer's field water and these habitats contain also lots of keratin debries. The collected water samples were analyzed for the physico-chemical parameters were represented in Table 1 and found that maximum numbers of fungi were present in the range of $\mathrm{pH} 6.25$ to 8.77 . In the present study most of the isolated keratinophilic fungi viz Epidermatophyton floccosum, Microsporum ferrugineum, Microsporum gypseum, Microsporum cookei, Microsporum canis, Trichophyton rubrum, Trichophyton mentagrophytes, Trichophyton concentricum, Trichophyton verrucosum, Trichophyton violaceum, other fungi were Aspergillus niger, Aspergillus fumigatus, Aspergillus flavus, Aspergillus terreus, 
Table 2. Isolation of keratinophilic and non- keratinophilic fungi from water samples of various habitats of Jharna and Bagru region by using different keratin substrates.

\begin{tabular}{|c|c|c|c|c|c|c|}
\hline \multirow{2}{*}{ S/no } & \multirow{2}{*}{ Source of water samples } & \multicolumn{4}{|c|}{ Keratin substrate for the Isolation of fungi } & \multirow{2}{*}{ Probable Genera } \\
\hline & & Hairs & nails & Duck Feather & Pigeon feather & \\
\hline 1. & Sewage water 1 (Jharna) & + & - & - & + & $\begin{array}{l}\text { Epidermatophyton } \\
\text { floccosum }\end{array}$ \\
\hline 2. & Trough water (Animal feeder) ( Jharna) & + & - & - & - & $\begin{array}{l}\text { Trichophyton } \\
\text { mentagrophytes }\end{array}$ \\
\hline 3. & Ditches water (Jharna) & - & + & - & - & T. rubrum \\
\hline 4. & $\begin{array}{l}\text { Waste water of dye textile industry } \\
\text { (Jharna) }\end{array}$ & - & + & + & - & T. concentricum \\
\hline 5. & Farmer's field water (Jharna) & - & - & - & + & T. verrucosum \\
\hline 6. & Trough water (Animal feeder) ( Bagru) & + & + & - & - & T. violaceum \\
\hline 7. & Duck Pond (Jharna) & - & - & + & + & M. gypseum \\
\hline 8. & Dye textile industry (Bagru) & - & - & + & + & M. ferrugineum \\
\hline 9. & Duck pond (Bagru) & - & - & - & + & M. cookei \\
\hline 10. & Farm house (Jharna) & + & - & - & - & Microsporum canis \\
\hline 11. & Wash room water $3($ Jharna) & + & - & + & + & Aspergillus niger \\
\hline 12. & Wash room water 2 (Jharna) & + & - & + & + & Aspergillus fumigatus \\
\hline 13. & Wash room water 1 (Jharna) & + & + & - & - & Aspergillus flavus \\
\hline 14. & Pond water (Jharna) & + & - & - & - & Aspergillus terreus \\
\hline 15. & Sewage water 2 (Jharna) & - & + & + & - & Rhizopus oryzae \\
\hline 16. & Duck pond/ Sink water (Jharna) & + & - & - & - & Penicillium sp. \\
\hline 17. & Baffallo Trough water (Bagru) & + & - & - & - & Fusarium oxysporum \\
\hline 18. & $\begin{array}{l}\text { Paper and pulp industry water (near } \\
\text { Bagru) }\end{array}$ & + & + & + & - & Chrysosporium tropicum \\
\hline
\end{tabular}

$+=$ Positive result (Growth observed), - = Negative result (No growth observed).

Rhizopus oryzae, Penicillium sp. and Fusarium oxysporum (Figure 2). Only one geophilic species of $M$. gypseum was isolated from one water sample out of twenty water samples. This work coincides with the Zarei (1997) who also isolated M. gypseum from the soil of Ahvaz. T. mentagrophytes, zoophilic species, isolated from the water habitat which was mainly harbors with hairs of humans, dogs, cows and buffaloes. $T$. mentagrophytes was found to be a dominant keratinophilic fungi in our study isolated from twenty water samples of various habitats of human beings and other animals. Our findings coincides with Rafiei et al. (1992), Deshmukh (2004) and Mussllam-Al (1989) who also isolated $T$. mentagrophytes from the soil of Ahvaz and Jhansi area respectively. The other species which were isolated in the present investigation include $E$. floccosum, $M$. ferrugineum, $T$. rubrum, $T$. concentricum, T. violaceum, A. niger, A. fumigatus, A. flavus, A. terreus, Rhizopus oryzae, Penicillium, F. oxysporum and Crysosporum tropicum were identified on the basis of microscopic, macroscopic and biochemical tests. The keratinase, urease and rice media test were found to be negative for $T$. verrucosum $M$. cookie and $M$. canis. Thus, $T$. verrucosum was identified on the basis of its isolation from trough water of buffalo habitat and microscopic, macroscopic characteristics. On the microscopic examination colony morphology was found to be white, cream and light brown and rat tail shaped macroconidia, pyriform macroconidia were observed. Improved growth at $30^{\circ} \mathrm{C}$ was also characteristic feature of $T$. verrucosum. $M$. cookie was identified on the basis of pale brown powdery to suede like appearance and reverse pigmentation was found dark brown and elliptical, thick walls and large size of macroconidia are diagnostic features of $M$. cookei. On Lactritmel Agar and Trichophyton Agar -1, good growth was observed which indicates the confirmation of $M$. cookei. Our findings were similar to Shadzi et al. (2002) who also isolated 214 keratinophilic fungi from the soil of schools and parks in Iran of which $T$. verrucosum and $M$ cookei were the most frequently reported. $M$. canis was identified on the basis of its primary isolation from dog and cat habitat. Colonies were white to cream with dense cottony growth with golden yellow reverse pigmentation, macroconidia were spindle shaped with 5-15 cells. Lactritmel Agar and Sabouraud's dextrose agar (SDA) media was found to be good for growth and sporulation of $M$. canis. Our findings were similar to Kaplan and Ivens (1961) who also isolated $M$. canis from cats and dogs. They considered that cats are to be reservoirs of infections. The present study concluded that different habitats viz. water of ditches, ponds and farm houses affect the isolation of 
Table 3. Microscopic and macroscopic characteristic of isolated fungi.

\begin{tabular}{|c|c|c|}
\hline Macroscopic Identification & Microscopic identification & Identified species \\
\hline $\begin{array}{l}\text { Green brown to khaki growth, yellowish } \\
\text { brown reverse pigmentation. }\end{array}$ & $\begin{array}{l}\text { Smooth, thin walled club shaped macroconidia } \\
\text { with hypae, macroconidia are absent. }\end{array}$ & Epidermatophyton floccosum \\
\hline $\begin{array}{l}\text { White to creamy, powdery growth and } \\
\text { yellow to brown reverse pigmentation. }\end{array}$ & $\begin{array}{l}\text { Single celled spherical shaped microconidia; } \\
\text { multicelled, clavate shaped macroconidia are } \\
\text { present. }\end{array}$ & Trichophyton mentagrophytes \\
\hline $\begin{array}{l}\text { Creamy growth and wine red reverse } \\
\text { pigmentation. }\end{array}$ & $\begin{array}{l}\text { Microconidia are Clavate to pyriform; } \\
\text { macroconidia are cylindrical. }\end{array}$ & T. rubrum \\
\hline $\begin{array}{l}\text { White to cream growth, yellow brown to } \\
\text { dark brown reverse pigmentation. }\end{array}$ & $\begin{array}{l}\text { Micro and macro conidia are absent, balloon } \\
\text { shaped chlamydoconidia are present. }\end{array}$ & T. concentricum \\
\hline $\begin{array}{l}\text { White to cream growth, yellow to } \\
\text { reddish brown reverse pigmentation. }\end{array}$ & $\begin{array}{l}\text { Microconidia are in pyriform and macroconidia } \\
\text { are absent instead of that chlamydoconidia are } \\
\text { present. }\end{array}$ & T. verrucosum \\
\hline $\begin{array}{l}\text { Violet, globrous or waxy growth, pinkish } \\
\text { reverse pigmentation. }\end{array}$ & $\begin{array}{l}\text { Hypae are relatively broad, much branched and } \\
\text { disorted. Numerous chlamydoconidia are } \\
\text { present. }\end{array}$ & T. violaceum \\
\hline $\begin{array}{l}\text { Creamy fluffy growth, yellow brown } \\
\text { reverse pigmentation. }\end{array}$ & $\begin{array}{l}\text { Clavate shaped microconidia; symmetrical and } \\
\text { ellipsoidal shaped macroconidia are present. }\end{array}$ & M. gypseum \\
\hline $\begin{array}{l}\text { Cottony growth, no reverse } \\
\text { pigmentation. }\end{array}$ & $\begin{array}{l}\text { No micro, macroconidia are present. Irregular } \\
\text { branching of hypae is present. }\end{array}$ & M. ferrugineum \\
\hline $\begin{array}{l}\text { Flate, pale yellow, powdery growth and } \\
\text { dark yellowish brown pigmentation. }\end{array}$ & $\begin{array}{l}\text { Micro conidia- elliptical and rough; } \\
\text { Macroconidia- cylindrical, clavate. }\end{array}$ & M. cookei \\
\hline $\begin{array}{l}\text { White to cream with dense cottony } \\
\text { growth; bright golden yellow reverse } \\
\text { pigmentation. }\end{array}$ & $\begin{array}{l}\text { Pyriform to clavate shaped micro conidia. } \\
\text { Macroconidia are spindle shaped with terminal } \\
\text { knoob. }\end{array}$ & Microsporum canis \\
\hline $\begin{array}{l}\text { Black growth, pale yellow reverse } \\
\text { pigmentation. }\end{array}$ & $\begin{array}{l}\text { Hypae are saptate, conidia are brown to black, } \\
\text { very rough and globose. }\end{array}$ & Aspergillus niger \\
\hline Blue green growth. & $\begin{array}{l}\text { Smooth walled conidiophores, conidia are } \\
\text { globose. }\end{array}$ & Aspergillus fumigatus \\
\hline $\begin{array}{l}\text { Dark yellow to green, flate, granular } \\
\text { growth. }\end{array}$ & Conidia are typically radiate. & Aspergillus flavus \\
\hline $\begin{array}{l}\text { Sand brown, suede like growth, yellow } \\
\text { to deep dirty yellow reverse } \\
\text { pigmentation. }\end{array}$ & Conidia are compact, globose to ellipsoidal. & Aspergillus terreus \\
\hline White to gray to blackish cottony growth. & $\begin{array}{l}\text { Smooth walled, non- saptate simple } \\
\text { sporangiospores, globose sporangia are } \\
\text { present. }\end{array}$ & Rhizopus oryzae \\
\hline Green, dense, flate growth. & $\begin{array}{l}\text { Single celled conidia, conidiophores are hyaline } \\
\text { and smooth walled. }\end{array}$ & Penicillium sp. \\
\hline
\end{tabular}


Table 3.contd.

Pinkish to purple growth, dark blue or dark purple reverse pigmentation.

White, flate, granular- powdery growth, pale brownish reverse pigmentation.
Macroconidia are fusiform, slightly curved, pointed tips and saptate, macroconidia are nonsaptate.

Fusarium oxysporum

Pyriform to clavate shaped conidia, macroconidia are absent.

Chrysosporium tropicum

Table 4. Biochemical tests for the identification of isolated fungi.

\begin{tabular}{llccc}
\hline S/no. & \multicolumn{1}{c}{ Identified species } & Keratinase test & Urease test & Rice media test \\
\hline 1. & Epidermatophyton floccosum & + & + & - \\
2. & Trichophyton mentagrophytes & + & + & - \\
3. & T. rubrum & + & - & - \\
4. & T. concentricum & + & + & - \\
5. & T. verrucosum & - & - & - \\
6. & T. violaceum & + & - & - \\
7. & M. gypseum & + & + & - \\
8. & M. ferrugineum & + & - & + \\
9. & M. cookei & - & - & - \\
10. & Microsporum canis & - & - & - \\
11. & Aspergillus niger & - & - & + \\
12. & Aspergillus fumigatus & - & - & - \\
13. & Aspergillus flavus & - & - & - \\
14. & Aspergillus terreus & - & - & + \\
15. & Rhizopus oryzae & - & - & - \\
16. & Penicillium sp. & - & - & - \\
17. & Fusarium oxysporum & - & - & - \\
18. & Chrysosporium tropicum & + & + & \\
\hline
\end{tabular}

$+=$ Positive result, $-=$ Negative result.

Table 5. Production of extracellular enzyme by isolated fungi obtained from water samples.

\begin{tabular}{lcccccccc}
\hline \multirow{2}{*}{ Enzymes } & \multicolumn{7}{c}{ Isolated fungi from water samples from various habitats } \\
\cline { 2 - 9 } & A .niger & A. fumigatus & A. flavus & A. terreus & R. oryzae & Penicillium & F. oxysporum \\
\hline Amylase & + & + & + & + & + & + & - & + \\
Protease & + & + & - & + & + & - \\
\hline
\end{tabular}

$+=$ Positive result, $-=$ Negative result.

keratinophilic fungi in the area of Jharna and Bagru region (Rajasthan).

\section{Conclusion}

The risk of fungi infections from the water is increasing in the environment day by day. From these results we find out different species of keratinophilic fungi are present in pond, farm house and textile industry water which causes superficial cutaneous infections in human beings and animals. According to these results it can be concluded that the water from farm houses, ponds and textile industry does not seemed to be ideal water for the human beings and the animals because they contain lots of keratinophilic and non -keratinophilic fungi which causes dermatophytosis or superficial cutaneous infections in human beings and animals. 

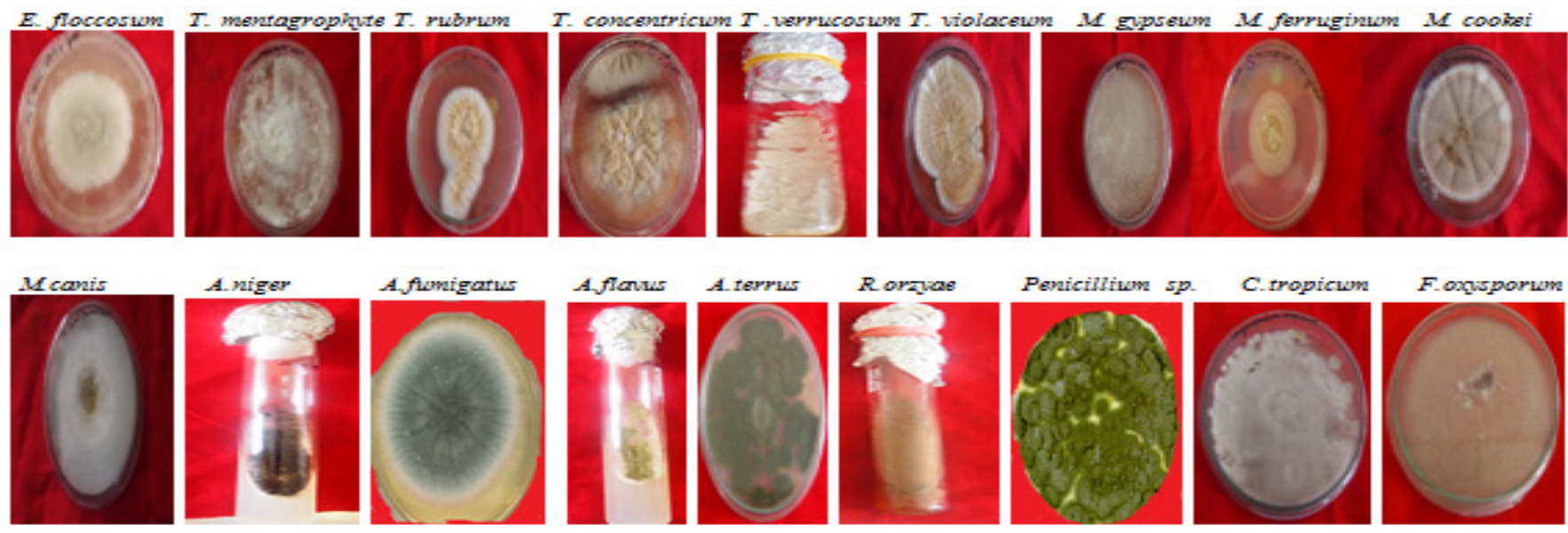

Figure 2. Identified Keratinophilic and non- keratinophilic Fungi from Bagru and Jharna area (Rajasthan).

\section{ACKNOWLEDGEMENT}

The authors are thankful to Dr. Panckaj Garg, Advisor, Jayoti Vidyapeeth Women's University for providing laboratory facilities used in this study.

\section{REFERENCES}

Awad MF, Kraume M (2011).Mycological survey of activated sludge in MBRs. Mycoses 54:493-498.

Berkenkamp B (1973). Qualitative Essays of Ribonuclease produced by plant pathogenic fungi. Canadian J. Microbiol. 19(143):1-1234.

Deshmukh SK (2004).Isolation of dermatophytes and other keratinophilic fungi from the vicinity of saitpan soil of Mumbai, India Mycopathol. 157:265-267.

Deshmukh SK, Mandeel QA, Verekar SA (2008). Keratinophilic fungi from selected soils of Bahrain. Mycopathol. 165(3):143-147.

Hedayati MT, Mohseni BA, Moradi SA (2004). Survey on the pathogenic fungi in soil sample of potted plants from sari hospitals, Iran. J. Hospital Infection. 58:59-62.

Hoog SD (1996). Effect of natural antifungals on keratinophilic fungi isolated from soil. Mycoses 39:407-417.

Kunert J, Kushwaha RKS, Guarro J (2000). Biology of Dermatophytes and other Keratinophilic Fungi.Revistalberoamericana De Micol. Bilbao 77-85.
Kaplan W, IvensM(1961). Observations on the seasonal variation in incidence of ringworm in dog and cats in the United States. Sabouraudia 1:91-94.

Mandeel Q, Simona N, Francesca M (2009). Keratinophilic fungi on feather of common clinically healthy birds in Bahrain. Mycoses 54(1):71-77.

Mussllam A (1989). Distribution of keratinophilic fungi in desert soil of Kuwait. Mycoses. 32:296-302.

Rafiei A, Emmami M, Moghadami M, Mahmedi M, Shidfar M (1992). Cutaneous mycosis in Khuzestan province.Ahvaz Scientific Medical J.14:22-34.

Shadzi S, Chadeganipour M, Ahmoradi M (2002).Isolation of keratinophilic fungi from elementary schools of public parks in Isfahan, Iran. Mycoses 45:469-499.

Wawrzkiewicz K, Wolski T, Lobarzewski J (1991).Screening the keratinolytic activity of dermatophytes in vitro. Mycopathol. 114:1-8.

Zarei MA (1997). A survey of 382 suspected patients with tinea capitis (Ahvaz). Ahvaz Scientific Medical J. 22:45-52. 